\title{
ANALISIS DAMPAK GAYA TUMBUKAN MELALUI PERUBAHAN BENTUK SEGI CRUSH INITIATOR PADA STRUKTUR TAILOR-WELDED BLANK
}

\author{
Felix Dionisius ${ }^{1}$, I'ah Wasiah ${ }^{2}$, Jos Istiyanto $^{3}$, Mohammad Malawat ${ }^{4}$, Bobi Khoerun ${ }^{5}$ \\ 1,2Jurusan Teknik Mesin Politeknik Negeri Indramayu, Jl. Raya Lohbener Lama no.8 Indramayu \\ ${ }^{5}$ Jurusan Teknik Pendingin dan Tata Udara Politeknik Negeri Indramayu, Jl. Raya Lohbener Lama no.8 \\ Indramayu \\ ${ }^{3,4}$ Departemen Teknik Mesin Fakultas Teknik, Universitas Indonesia, Kampus Depok Baru \\ Email: ${ }^{1}$ dionisiusfelix @ gmail.com, ${ }^{2}$ iahgufxiah01@ gmail.com, ${ }^{3}$ josist@eng.ui.ac.id, ${ }^{4}$ \\ m.malawat72@gmail.com, ${ }^{5}$ hubbikhoiron31@gmail.com
}

\begin{abstract}
Abstrak
Struktur Tailor-welded blank (TWB) merupakan salah satu model komponen kendaraan yang digunakan pada bagian kendaraan. Selain itu, struktur tersebut dapat dipakai dalam teknologi crashworthiness dimana dapat mengurangi cedera saat terjadi tabrakan. Struktur kendaraan yang mempunyai kekuatan beban lebih besar mengakibatkan penumpang dapat terlempar dari ruang penumpang. Makalah ini membahas mengenai pengaruh lubang berbentuk segi 4;6;8 sebagai crush initiator yang dipasang pada TWB terhadap gaya tumbukan maksimum selama pembebanan termasuk desain terbaik dimana meliputi nilai terkecil. Metode yang digunakan merupakan pembebanan kuasi statik secara eksperimental seperti kecepatan aktuator sebesar $0,5 \mathrm{~mm} / \mathrm{s}$ hingga mencapai deformasi sebesar $9,55 \mathrm{~mm}$. TWB terbuat dari pembentukan plat dengan proses stamping hingga spot weld. Hasilnya menunjukkan gaya tumbukan maksimum mengalami peningkatan berbanding lurus terhadap penambahan bentuk segi crush initiator sebesar $14633 \mathrm{~N}$ hingga $18705 \mathrm{~N}$. Dari hasil tersebut dapat diketahui lubang bentuk segi 4 sebagai desain terbaik dalam memperoleh gaya tumbukan maksimum terkecil.
\end{abstract}

Kata Kunci: crashworthiness, crush initiator, bentuk segi, gaya tumbukan maksimum, tailorwelded blank

\begin{abstract}
Tailor-welded blank (TWB) structure is one of the vehicle component models used in vehicle parts. In addition, these structures can be used in crashworthiess technology which can reduce injuries during a collision. The structure of a vehicle that has greater strength can cause passengers to be thrown from the passenger compartment. This paper discusses the effect of faceted holes such as square, hexagonal and octagonal as crush initiator mounted on TWB which results in a maximum impact force $\left(F_{\max }\right)$. The smallest maximum impact force is the criteria achieved from this study. The method used experimental quasi-static loading of the actuator speed of $0.5 \mathrm{~mm} / \mathrm{s}$ to achieve $9.55 \mathrm{~mm}$ of deformation. TWB was made from plate formation with a process of stamping to spot weld. The result showed that the maximum impact force has an increase directly proportional to the addition of the shape of the crush initiator in the amount of $14.633 \mathrm{kN}$ to $18.705 \mathrm{kN}$. From these results, it can be seen a square hole as best design in obtaining the smallest maximum impact force.
\end{abstract}

Keywords: Crashworthiness, crush initiator, faceted holes, peak force, tailor-welded blank.

\section{PENDAHULUAN}

Struktur ringan banyak digunakan dalam dunia kendaraan, yang mempunyai keuntungan dalam sisi ekonomis salah satunya dapat mengurangi konsumsi energi bahan bakar. Selain itu struktur tersebut mempuyai manfaat dalam sisi keselamatan yang dapat mengurangi cedera saat terjadi tabrakan yang dikenal dengan nama crashworthiness. Energi yang dihasilkan dapat terserap melalui struktur 
ringan (Abramowicz, 2003) saat terjadi kerusakan yang dinamakan dengan daerah penghancuran dan mengalami progressive buckling (Abramowicz \& Jones, 1986). Pada umumnya daerah tersebut berada di daerah depan dengan menyerap energi kinetik sebesar $40 \%$ (Istiyanto, et al., 2014) yang dinamakan dengan front rail. Salah satu metode yang dilakukan untuk meningkatkan kemampuan crashworthiness adalah dengan menambahkan crush initiator.

Cho dkk (Cho, et al., 2006) sudah melakukan optimasi ukuran dan kedalaman lekukan serta lubang lingkaran sebagai initiator pada spesimen tabung berpenampang lingkaran dan kotak pada bagian depan kendaraan untuk mendapatkan yang lebih besar dan dapat dihasilkan melalui pengujian secara eksperimental dan simulasi numerik menggunakan PAM-Crash. Lubang berbentuk $V$ notch dan kedalaman alur sebagai initiator pada spesimen hollow persegi juga sudah diinvestigasi oleh beberapa peneliti (Balaji \& Annamalai, 2017; Xu, et al., 2016; Marzbanrad, et al., 2014) dengan melakukan uji tabrakan. Spesimen tersebut banyak digunakan pada bagian depan kendaraan. Chen dkk (Chen, et al., 2017) melakukan optimasi pada kolom berpenampang octagonal yang diberikan pembebanan kuasi dinamik dengan kecepatan 50 $\mathrm{km} / \mathrm{h}$ dengan arah sudut benturan yang berbeda. Pengujian ini menggunakan metode eksperimental dan numerikal dengan bantuan LS-DYNA. Kolom tersebut mempunyai ketebalan yang berbeda beda dalam satu kondisi desain yang disebut kolom functionally graded thickness (FGT).

Dengan menggunakan lubang lingkaran yang diletakkan pada kolom struktur berdinding tipis juga diuji benturan untuk menurunkan gaya tumbukan maksimum dan meningkatkan penyerapan enerrgi yang terjadi saat benturan (Dirgantara, et al., 2013; Estrada, et al., 2017; Malawat, et al., 2017; Nghia, et al., 2014; Mamalis, et al., 2009; Subramaniyan, et al., 2014; Istiyanto, et al., 2014). Selain itu dengan variasi posisi atau jarak lubang lingkaran dari ujung spesimen struktur tabung juga sudah diteliti oleh Estrada dkk (Estrada, et al., 2017) serta Malawat dkk (Malawat, et al., 2017). Khalili dkk (Khalili, et al., 2015) melakukan investigasi terhadap kolom segi empat dengan variasi ketebalan dinding, panjang kolom, ratio penampang dan koefisien gesekan serta massa dari impaktor dalam menentukan penyerapan energi spesifik, beban tumbukan maksimum dan deformasi yang terjadi saat dilakukan pengujian tabrakan. Pengujian ini menggunakan metode simulasi numerik secara kuasi dinamik dimana kecepatan awal impaktor sebesar $15 \mathrm{~m} / \mathrm{s}$. Bambach dkk (Bambach, et al., 2016) melakukan pengujian crashworthiness pada kolom hexagonal dengan menggunakan material paduan steel-mangan Fe28Mn0.3C dan Fe23Mn1.25Al0.3C dimana mempunyai kekuatan dan keueletan yang tinggi. Kolom tersebut dilakukan proses homogenization dengan metode forging dan proses hot rolled untuk mendapatkan ketebalan yang sesuai. Setelah itu kolom diberikan local heat treatment menggunakan laser sebagai initiator. Pengujian ini dilakukan dengan metode beban jatuh beban yang mempunyai massa sebesar $253 \mathrm{~kg}$ dengan ketinggian 2,16 m.

Asanjarani dkk (Asanjarani, et al., 2017) melakukan optimasi multiobjective antara penyerapan energi spesifik dan efisiensi gaya tumbukan pada kolom berdinding tipis berbentuk tapered dan mempunyai lekukan sebagai crush initiator saat pengujian crashworthiness dengan menggunakan simulasi numerik Abaqus. Rezvani dkk (Rezvani \& Jahan, 2015) memanfaatkan initiator pad tabung lingkaran berdinding tipis yang diisi oleh polyurethane foam dimana hollow tersebut berbentuk cincin anular dalam meningkatkan penyerapan energi spesifik. Zhang dkk (Zhang, et al., 2009) meletakkan buckling initiator pada ujung spesimen hollow dimana tabrakan tidak langsung mengenai tabung persegi dengan material aluminium.

Makalah ini bertujuan untuk mengetahui kemampuan crashworthiness yang paling baik khususnya gaya tumbukan maksimum terkecil pada tailor-welded blank (TWB) dengan variasi lubang berbentuk segi sebagai crush initiator. Pada umumnya, TWB digunakan pada bagian depan kendaraan seperti sled car untuk menyerap energi saat terjadi benturan seperti yang dilakukan oleh Fengxiang (Fengxiang, et al., 2018). Selain itu, TWB juga diinvestigasi ole $\mathrm{Xu}$ (Xu, et al., 2014) dengan penggabungan beberapa kolom yang berbeda kekuatan melalui proses laser welding. Sedangkan TWB dalam penelitian ini menggunakan profil channel dan plat dimana penggabungan melalui proses spot welding.

\section{METODE}

Penelitian ini menggunakan diagram alir sebagai tahapan dalam memperoleh kriteria crashworthiness salah satunya gaya tumbukan maksimum yang ditunjukkan pada Gambar 1.

Pembuatan TWB diawali dengan proses pembuatan crush initiator dimana plat mengalami proses blanking menggunakan mesin press $\mathrm{CNC}$ dengan variasi penambahan segi pada lubang antara lain segi 4; 6; dan 8 serta lingkaran. Variasi 
lubang tersebut sebagai desain eksperimen dan dibuat dengan mempertimbangkan nilai luasan yang sama antara bentuk segi seperti yang ditunjukkan pada Gambar 2. Kemudian dilanjutkan dengan proses stamping sehingga membentuk ukuran penampang channel 40 x $40(\mathrm{~mm})$. Proses spot welding diperlukan untuk menyatukan plat dan channel sehingga membentuk menyerupai penampang persegi yang disebut dengan Tailorwelded blank (TWB) dengan panjang spesimen 200 $\mathrm{mm}$.

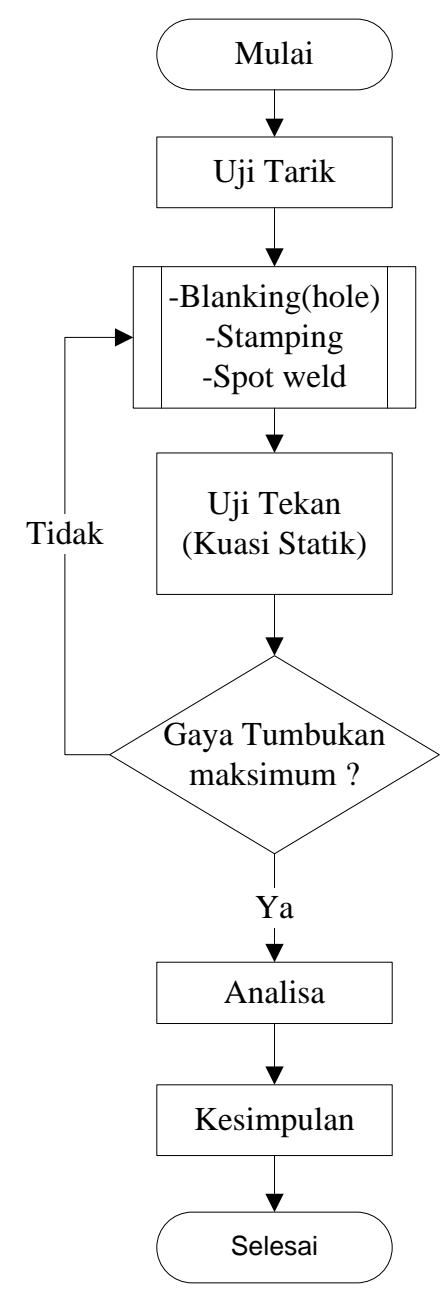

Gambar 1. Diagram alir

\section{Uji Tarik}

Pengujian tarik dilakukan untuk mengetahui sifat mekanik dari suatu material. Spesimen dibentuk dengan mengikuti standard ASTM E8/E8M dan menggunakan mesin Universal Testing Machine (UTM) berkapasitas 20ton seperti yang ditunjukkan pada Gambar 3. Material tersebut mempunyai poisson's ratio 0.3 , massa jenis 7850 $\mathrm{kg} / \mathrm{m}^{3}$, tegangan luluh $\left(\sigma_{\mathrm{y}}\right) 236,78 \mathrm{MPa}$, tegangan maksimum $\left(\sigma_{\mathrm{u}}\right) \quad 413,42 \mathrm{MPa}$ dan regangan maksimum (E) mencapai $34,16 \%$.

\section{Konsep Pengujian Crashworthiness}

Crashworthiness merupakan salah satu teknologi yang digunakan pada kendaraan pada saat kecelakaan yang digunakan untuk melalui struktur berdinding tipis. Pengujian crashworthiness dilakukan dengan metode beban tekan aksial secara kuasi statik dengan kecepatan aktuator $0,5 \mathrm{~mm} / \mathrm{s}$ hingga mencapai deformasi sebesar $9,55 \mathrm{~mm}$. Deformasi ini dihasikan melalui studi yang dilakukan oleh Wierzbicki (Wierzbicki \& Abramowicz, 1983) yang merupakan panjang awal lipatan. Konsep pengujian ini dapat dilihat pada Gambar 4. Pengujian ini menghasilkan grafik antara parameter beban aksial terhadap deformasi yang terjadi saat benturan. Dari grafik tersebut, dapat menghasilkan beban tumbukan maksimum.

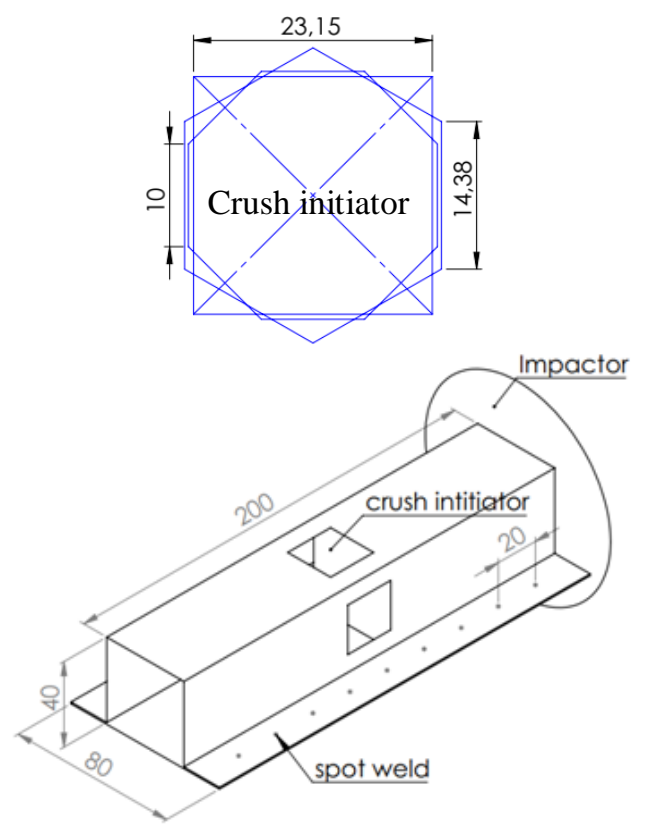

Gambar 2. Desain TWB

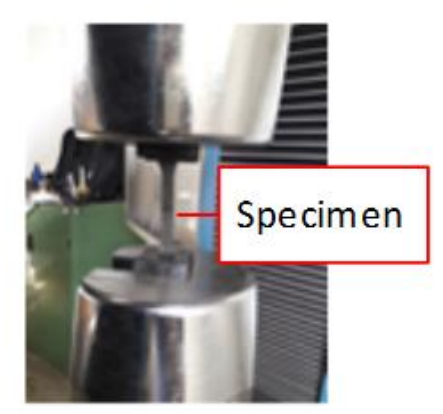

Gambar 3. Uji Tarik

\section{HASIL DAN PEMBAHASAN}

Pengujian kuasi statik merupakan salah satu pengujian yang dilakukan untuk mengetahui karakteristik awal suatu komponen struktur dalam proses buckling (Johnson, et al., 1977; 
Abramowicz \& Jones, 1997). Proses buckling terlebih dahulu tampak berada di daerah crush initiator tepatnya berada di tengah crush initiator seperti yang ditunjukkan pada Gambar 5a. Melalui pengujian tekan secara kuasi statik pada mesin Universal Testing Machine dapat dihasilkan gaya terhadap deformasi. Pada saat awal buckling, gaya mengalami kenaikan hingga menunjukkan gaya tumbukan maksimum yang terjadi untuk setiap bentuk segi crush initiator seperti yang ditunjukkan pada Gambar 5b

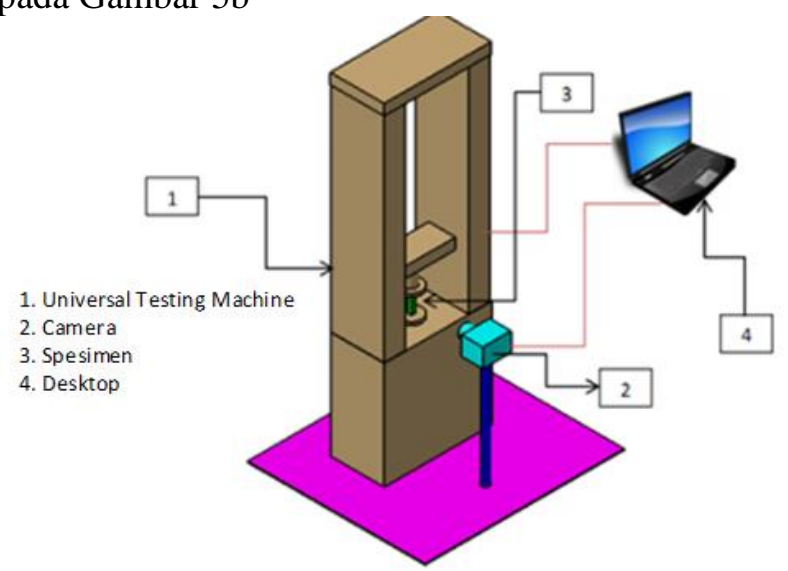

Gambar 4. Konsep Pengujian

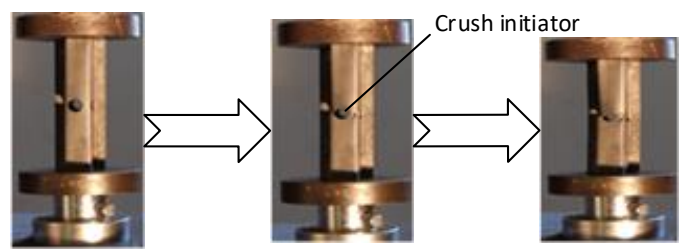

(a)

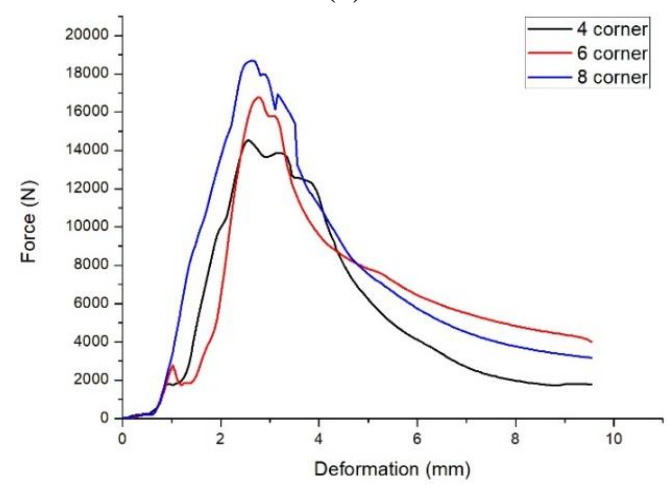

(b)

Gambar 5. Pengujian tekan kuasi statik: a) Initial buckling; b) kurva gaya vs deformasi

Spesimen TWB yang diberikan crush initiator akan mengalami gaya tumbukan maksimum saat deformasi berada pada daerah $3 \mathrm{~mm}$. Jika dikaitkan dengan kecepatan aktuator yang konstan, maka waktu saat terjadi gaya maksimum terjadi pada saat 6 detik untuk pembebanan kuasi statik. Dari perubahan bentuk segi yang diberikan pada spesimen sebagai crush initiator, hasilnya menunjukan crush intiator berbentuk persegi dimana gaya tumbukan maksimum paling rendah sebesar $14.633 \mathrm{~N}$ diikuti segi 6 dan 8 sebesar $15.734 \mathrm{~N}$ dan $18.705 \mathrm{~N}$. Jika dihubungkan dengan kriteria crashworthiness terbaik, bentuk persegi merupakan desain terbaik dalam memperoleh gaya tumbukan maksimum terkecil.

Peningkatan gaya tumbukan maksimum dengan variasi bentuk segi terjadi melalui stress concentration factor (SCF). Nilai dari SCF akan mempengaruhi nilai dari gaya tumbukan maksimum pada setiap spesimen dimana pengaruh antar kedua nilai akan berbanding lurus. Hal ini juga telah dilakukan oleh Nghia et al (Nghia, et al., 2013) dengan melakukan prediksi secara analitik pada spesimen kolom persegi yang diberikan variasi diameter lubang lingkaran sebagai crush initiator. SCF ini dapat ditelusuri dengan melakukan analisa teoritik maupun metode elemen hingga (Schmid, et al., 2014) dengan perbandingan tegangan maksimum dan tegangan normal. Makalah ini menggunakan metode elemen hingga dengan permodelan simulasi numerik Solidworks Simulation untuk mengetahui tegangan maksimum yang terjadi pada suatu plat yang diberikan lubang crush initiator dengan bentuk segi yang berbeda antara lain segi 4,6 , dan 8 . Kedua ujung dari sebuah plat yang berukuran $40 \times 40 \times 200 \mathrm{~mm}$ dengan ketebalan $0,8 \mathrm{~mm}$ ditarik dengan pembebanan $1000 \mathrm{~N}$ pada masing masing ujung plat seperti yang ditunjukkan pada Gambar 6 . Permodelan ini dilakukan pada setiap kondisi spesimen.

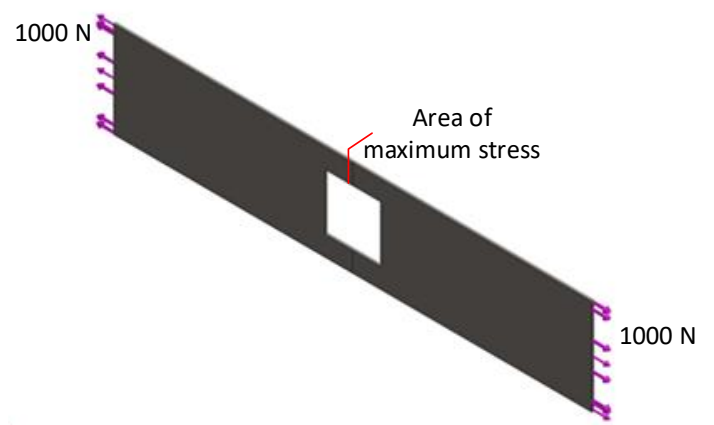

Gambar 6. Diagram Benda Bebas untuk stress concentration factor

Daerah tegangan maksimum ditempatkan pada daerah tengah crush initiator karena pada daerah tersebut terjadinya awal buckling. Simulasi numerik menunjukkan SCF mengalami peningkatan yang berbanding lurus terhadap variabel penambahan bentuk segi sebesar 1,286 
hingga 1,62 . Hal ini berdampak pada peningkatan gaya tumbukan maksimum pada TWB yang diberikan crush initiator.

\section{PENUTUP}

\section{Kesimpulan}

Tailor-welded blank (TWB) merupakan spesimen kolom berdinding tipis yang diuji pada penelitian ini dalam mengetahui kemampuan crashworthiness seperti gaya tumbukan maksimum yang terjadi saat pemebebanan kuasi statik. Gaya tumbukan dapat berpengaruh terhadap cedera pada penumpang dimana dalam penelitian ini kriteria crashworthiness terbaik merupakan gaya tumbukan maksimum terkecil. Variabel yang digunakan dalam penelitian ini adalah dengan memberikan lubang bentuk segi seperti persegi (segi 4), hexagonal (segi 6) dan octagonal (segi 8) sebagai crush initiator yang diletakkan di tengah sisi dari spesimen. Gaya tumbukan maksimum mengalami peningkatan berbanding lurus terhadap penambahan bentuk segi sebesar $14.633 \mathrm{~N}$ hingga 18.705 N. Dari hal tersebut, dapat disimpulkan bahwa bentuk lubang persegi (segi 4) merupakan desain terbaik dalam menghasilkan gaya tumbukan maksimum dibandingkan dengan bentuk segi lain dimana merupakan kriteria crashworthiness terbaik.

\section{DAFTAR PUSTAKA}

Abramowicz, W. \& Jones, N., 1986. Dynamic Progressive Buckling of Circular and Square Tubes. International Journal of Impact Engineering, 4(4), pp. 243-270.

Abramowicz, W. \& Jones, N., 1997. Transition from Initial Global Bending to Progressive Buckling of Tubes Loaded Statically and Dynamically. International Journal of Impact Engineering, 19(5-6), pp. 415-437.

Abramowicz, W., 2003. Thin-walled structures as impact energy absorbers. Thin-Walled Structures, 41(2-3), pp. 91-107.

Asanjarani, A., Dibajian, S. H. \& Mahdian, A., 2017. Multi-objective crashworthiness optimization of tapered thin-walled square tubes with indentations. Thin-Walled Structures, Volume 116, pp. 26-36.

Balaji, G. \& Annamalai, K., 2017. An experimental and numerical scrunity of crashworthiness variables for aquae column with $\mathrm{V}$-notch and groove initiators under quasi-static loading. Cogent Engineering, Volume 4, pp. 1-20.
Bambach, M. et al., 2016. Enhancing the crashworthiness of high-manganese steel by strain-hardening engineering, and tailored folding by local heat-treatment. Materials and Design, Volume 110, pp. 157-168.

Chen, Y. et al., 2017. Crashworthiness analysis of octagonal multi-cell tube with functionally graded thickness under multiple loading angles. Thin-Walled Structures, Volume 110, pp. 133-139.

Cho, Y.-B., Bae, C.-H., Suh, M.-W. \& Sin, H.-C., 2006. A vehicle front frame crash design optimization using hole-type and dent-type crush initiator. Thin-Walled Structures, Volume 44, pp. 415-428.

Dirgantara, T. et al., 2013. Numerical and Experimental Impact Analysis of Square Crash Box Structure With Holes. Applied Mechanics and Materials, Volume 393, pp. 447-452.

Estrada, Q. et al., 2017. Crashworthiness behavior of aluminum profiles with holes considering damage criteria and damage evolution. International Journal of Mechanical Sciences, Volume 131-132, pp. 776-791.

Fengxiang, X., Zhang, S., Wu, K. \& Dong, Z., 2018. Multi-response optimization design of tailor-welded blank (TWB) thin-walled structures using Taguchi-based gray relational analysis. Thin-Walled Structures, 131(286), p. 296.

Istiyanto, J. et al., 2014. Experiment and Numerical Study-Effect of crush intiators under quasistatic axial load of thin wall square tube. Applied Mechanics and Materials, Volume 660, pp. 628-632.

Johnson, W., Soden, P. D. \& Al-Hassani, S. T., 1977. Inextensional collapse of thin-walled tubes under axial compression. The Journal of Strain Analysis for Engineering Design, 12(4), pp. 317-330.

Khalili, P., Tarlochan, F., Hamouda, A. S. \& AlKhalifa, K., 2015. Energy absorption of thinwalled aluminium tubes under crash loading. Journal of Mechanical Engineering and Sciences (JMES), Volume 9, pp. 1734-1743.

Malawat, M., Istiyanto, J. \& Sumarsono, D. A., 2017. Effects of Wall Thickness and Crush Initiators Position under Experimental Drop Test on Square Tubes. Applied Mechanics and Materials, Volume 865, pp. 612-618.

Mamalis, A. G. et al., 2009. The effect of the implementation of circular holes as crush 
initiators to the crushing characteristics of mild steel square tubes: experimentl and numerical simulation. International Journal of Crashworthiness, 14(5), pp. 489-501.

Marzbanrad, J., Ebrahimi-F, M. \& Khosravi, M., 2014. Optimization of crush initiators on steel front rail of vehicle. International Journal of Automotive Engineering, 4(2), pp. 749-757.

Nghia, N. C. et al., 2013. Analytical Prediction of Square Crash Box Structure with Holes due to Impact Loading. Kuala Lumpur, s.n.

Nghia, N. C. et al., 2014. Impact Behavior of Square Box Structures Having Holes at Corners. Applied Mechanics and Materials, Volume 660, pp. 613-617.

Rezvani, M. J. \& Jahan, A., 2015. Effect of initiator, design, and material on crashworthiness performance of thin-walled cylindrical tubes : A primary multi-criteria analysis in lightweight design. Thin-Walled Structures, Volume 96, pp. 169-182.

Schmid, S. R., Hamrock, B. J. \& Jacobson, B. O., 2014. Failure Prediction for Static Loading. In: Fundamentals of Machine Elements. Northwest, Washington, D.C.: Taylor \& Francis Group, LLC, p. 134.

Subramaniyan, S. K. et al., 2014. Crush Characteristics and Energy Absorption of Thin-Walled Tubes with Through-Hole Crush Initiators. Applied Mechanics and Materials, Volume 606, pp. 181-185.

Wierzbicki, T. \& Abramowicz, W., 1983. On the Crushing Mechanics of Thin-Walled Structures. Journal of Applied Mechanics, Volume 50, pp. 727-734.

Xu, F., Sun, G., Li, G. \& Li, Q., 2014. Experimental study on crashworthiness of tailor-welded blank (TWB) thin-walled highstrength steel (HSS) tubular structures. ThinWalled Structures, Volume 74, pp. 12-27.

$\mathrm{Xu}$, P. et al., 2016. Cut-out grooves optimixation to improve crashworthiness of a gradual energy-absorbing structure for subway vehicle. Materials and Design, Volume 103, pp. 132-143.

Zhang, X. W., Su, H. \& Yu, T. X., 2009. Energy absorption of an axially crushed square tube with a buckling initiator. International Journal of Impact Engineering, Volume 36, pp. 402-417. 